Jurnal Akuntansi dan Bisnis: Jurnal Program studi Akuntansi, 5 (1) Mei 2019.

ISSN 2443-3071 (Print) ISSN 2503-0337 (Online). DOI: 10.31289/iab.v5i1.2223

JURNAL AKUNTANSI DAN BISNIS

Jurnal Program Studi Akuntansi

Available online http://ojs.uma.ac.id/index.php/jurnalakundanbisnis

\title{
FAKTOR-FAKTOR YANG MEMPENGARUHI MARGIN LABA BERSIH PERUSAHAAN OTOMOTIF DAN KOMPONENNYA YANG TERDAFTAR DI BURSA EFEK INDONESIA
}

\author{
Ruth Veny Martha ${ }^{a^{*}}$, Benny Franco Sitompul $a$ \\ ${ }^{a}$ Universitas Prima Indonesia
}

Diterima Januari 2019; Disetujui Maret 2019; Dipublikasikan Mei 2019

\begin{abstract}
Abstrak
Penelitian ini bertujuan untuk mengetahui seberapa besar pengaruh rasio lancar, rasio hutang terhadap ekuitas, total perputaran aset secara simultan terhadap margin laba bersih pada perusahaan otomotif dan komponennya yang terdaftar di Bursa Efek Indonesia dari 2013 hingga 2016. Data yang digunakan adalah rasio lancar, rasio utang terhadap ekuitas, perputaran total aset dan perusahaan margin laba bersih. Koefisien determinasi, Uji F dan Uji T digunakan dalam penelitian ini. Hasil penelitian ini menunjukkan efek simultan dari rasio lancar, rasio hutang terhadap ekuitas, dan total perputaran aset memiliki dampak yang signifikan terhadap margin laba bersih.
\end{abstract}

Kata Kunci : Rasio Lancar, Rasio Modal Terhadap Hutang, Perputaran Total Aset, Margin Laba Bersih

\begin{abstract}
This study aims to determine how much influence current ratio, debt to equity ratio, total asset turnover simultaneously on net profit margin on otomotive companies and component listed on The Indonesia Stock Exchange from 2013 to 2016. The data used are the current ratio, debt to equity ratio, total asset turnover and net profit margin's company. Coeficient determination, $F$ Value and T Test are using in this study. The result of this study is simultaneous effect of current ratio, debt to equity ratio, and total asset turnover have a significant impact on net profit margin.
\end{abstract}

Keyword: Current Ratio, Debt to Equity Ratio, Total Asset Turnover dan Net Profit Margin.

How To Cite: Martha, R.V, \& Sitompul, B.F. (2019). Faktor-faktor yang mempengaruhi margin laba bersih perusahaan otomotif dan komponennya yang terdaftar di Bursa Efek Indonesia. Jurnal Akuntansi dan Bisnis: Jurnal Program Studi Akuntansi, 5 (1): 34 -40

* email: ruthvenymartha@gmail.com

\section{PENDAHULUAN}

Kelangsungan hidup perusahaan dipengaruhi oleh banyak hal antara lain margin laba yang dihasilkan pada laporan keuangan perusahaan. Margin laba tersebut merupakan salah satu faktor untuk menilai baik buruknya kinerja perusahaan. Beberapa rasio biasa digunakan untuk mengukur efektivitas perusahaan. Adapun faktor-faktor yang dapat mempengaruhi margin laba suatu perusahaan diantaranya rasio lancar, rasio hutang terhadap ekuitas, total perputaran aset (Barus, A. C. 2013).

Pada umumnya pendirian suatu perusahaan bertujuan untuk memaksimalkan keuntungan yang diperoleh agar kelangsungan hidup usahanya terjamin dan dapat 
mengembangkan usahanya. Bagi perusahaan masalah profitabilitas sangat lah penting salah satunya di perusahaan otomotif dan komponennya. Bagi perusahaan, net profit margin dapat digunakan sebagai tolak ukur berhasil atau tidaknya perusahaan yang dipimpinnya. Karena perusahaan menghasilkan keuntungan bersih setelah dipotong pajak (Dewi, \& Hidayat 2019).

Perusahaan dapat dikatakan sehat apabila perusahaan dapat memenuhi kewajiban financial keuangan serta bisa melangsungkan kegiatan operasional dan mengembangkan usahanya. Dalam hal ini Current ratio menunjukkan kemampuan perusahaan untuk membayar hutang lancar dengan jaminan aktiva lancar. Masalah pada aktiva lancar yaitu menumpuk pada persedian yang terlalu banyak dimana dapat menimbulkan resiko keuangan sehingga mempengaruhi keuntungan perusahaan dan kemampuan membayar hutang lancarnya. Dalam penelitian Basuki \& Djoko (2012) ROA dan DER berpengaruh signifikan terhadap margin laba pada perusahaan otomotif yang terdaftar di bursa efek indonesia

Berdasarkan penjelasan diatas maka dapat diambil sebuah kerangka konsep mengenai pengaruh Current ratio, Debt to Equity ratio, Total Aset Turnover berpengaruh terhadap Net Profit Margin yang dapat digambarkan dalam gambar sebagai berikut:

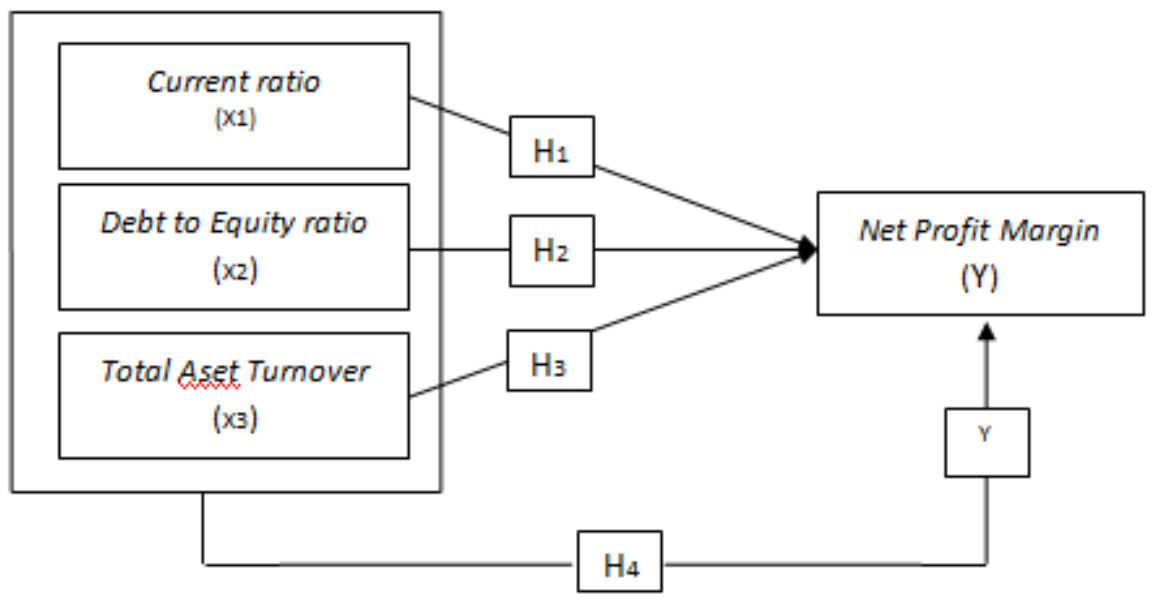

Gambar 1.1 Kerangka Konseptual

Perusahaan yang mampu dalam membayar hutang lancarnya sangat mempengaruhi pertumbuhan laba suatu perusahaan, Current Ratio adalah salah satu alat ukur analisis yang digunakan dalam pengukurannya (Basuki \& Djoko 2012).

\section{METODE PENELITIAN}

Data dalam penelitian ini adalah data sekunder yang diambil pada website bursa efek indonesia pada perusahaan otomotif dan komponennya yang terdaftar di bursa efek indonesia periode 2013-2016.

Untuk analisis yang digunakan yakni meliputi perhitungan current ratio, debt to equity ratio, total asset turnover. Ketiga analisis tersebut digunakan untuk mengetahui analisis dekriptif statistik yang dalam melihat pengaruhnya kepada net profit margin 


\section{HASIL DAN PEMBAHASAN}

Pengujian hipotesis yang digunakan dalam penelitian adalah dengan menggunakan analisis regresi berganda. Hasil dari model regresi yang digunakan dapat dilihat dalam tabel 1.1 sebagai berikut :

Tabel 1.1 Persamaan Regresi

\begin{tabular}{|c|c|c|c|c|c|c|c|c|}
\hline \multicolumn{9}{|c|}{ Coefficients $^{a}$} \\
\hline & \multirow[t]{3}{*}{ Model } & \multirow{2}{*}{\multicolumn{2}{|c|}{$\begin{array}{l}\text { Unstandardized } \\
\text { Coefficients }\end{array}$}} & \multirow{4}{*}{$\begin{array}{c}\text { Standardized } \\
\text { Coefficients } \\
\text { Beta }\end{array}$} & \multirow[t]{4}{*}{$\mathrm{t}$} & \multirow[t]{4}{*}{ Sig. } & \multirow{2}{*}{\multicolumn{2}{|c|}{$\begin{array}{l}\text { Collinearity } \\
\text { Statistics }\end{array}$}} \\
\hline & & & & & & & & \\
\hline & & B & Std. & & & & Tolerance & VIF \\
\hline \multicolumn{6}{|c|}{ Error } & & & \\
\hline \multirow{4}{*}{1} & (Constant) & -3.131 & .201 & & -15.613 & .000 & & \\
\hline & LN_Current_Ratio & -.173 & .171 & -.167 & -1.016 & .318 & .944 & 1.060 \\
\hline & LN_Debt_To_Equity_Ratio & -.536 & .241 & -.361 & -2.224 & .034 & .970 & 1.031 \\
\hline & LN_Total_Aset_Turnover & -.731 & .265 & -.453 & -2.759 & .010 & .945 & 1.058 \\
\hline
\end{tabular}

a. Dependent Variable: LN_Net_Profit_Margin

$$
\text { LN Y = -3.131-0.173 LN X }-0.536 \text { LN X }_{2}-0,731 \text { LN X }_{3}
$$

Dapat dijabarkan dari persamaan regresi linear berganda bahwa kostanta sebesar 3.131 menyatakan jika current ratio, debt to equity ratio, dan total asset turnover kostan maka net profit margin sebesar -3.131 rupiah. Selanjutnya, koefisien regresi current ratio sebesar - 0.173 dan bernilai negatif menyatakan bahwa setiap kenaikan current ratio satu satuan akan menyebabkan penurunan net profit margin sebesar -0.173 rupiah. Koefisien regresi debt to equity ratio sebesar -0.536 dan bernilai negatif menyatakan bahwa setiap kenaikan debt to equitysatu satuan akan menyebabkan penurunannet profit margin sebesar -0.536 rupiah. Koefisien regresi total asset turnover sebesar -0.731 dan bernilai negative menyatakan bahwa setiap kenaikan total asset turnoversatu satuan akan menyebabkan penurunannet profit margin sebesar -0.731 .

Koefisien determinasi $\left(\mathrm{R}^{2}\right)$ dapat diartikan untuk mengukur seberapa jauh kemampuan model dalam menerangkan variabel-variabel dependen. Jika koefisien determinasi $\left(\mathrm{R}^{2}\right)$ semakin besar atau mendekati 1 , maka dapat dikatakan bahwa kemampuan variabel Independen $(\mathrm{X})$ adalah besar terhadap variabel dependen (Y), hasi dari koefisien determinsai tersebut dapat dilihat pada tabel 1.2 dibawah ini.

Tabel 1.2 Uji Koefisien Determinasi

\begin{tabular}{|c|c|c|c|c|c|c|c|c|c|c|}
\hline \multicolumn{11}{|c|}{ Model Summaryb } \\
\hline \multirow{3}{*}{$\begin{array}{c}\text { Mod } \\
\text { el }\end{array}$} & \multirow[t]{3}{*}{$\mathrm{R}$} & \multirow{3}{*}{$\begin{array}{c}\mathrm{R} \\
\text { Square }\end{array}$} & \multirow{3}{*}{$\begin{array}{l}\text { Adjusted } \\
\text { R Square }\end{array}$} & \multirow{3}{*}{$\begin{array}{l}\text { Std. Error } \\
\text { of the } \\
\text { Estimate }\end{array}$} & \multicolumn{5}{|c|}{ Change Statistics } & \multirow{3}{*}{$\begin{array}{l}\text { Durbin- } \\
\text { Watson }\end{array}$} \\
\hline & & & & & R Square & $\mathrm{F}$ & df1 & df2 & Sig. F & \\
\hline & & & & & Change & Change & & & Change & \\
\hline 1 & $.534^{\mathrm{a}}$ & .285 & .209 & .84042 & .285 & 3.727 & & $2 \varepsilon$ & .023 & 1.757 \\
\hline
\end{tabular}

a. Predictors: (Constant), LN_Total_Aset_Turnover, LN_Debt_To_Equity_Ratio, LN_Current_Ratio

b. Dependent Variable: LN_Net_Profit_Margin 
Hasil uji koefisien determinasi diperoleh nilai Adjusted $R$ square sebesar -0.209. Hal ini menunjukkan bahwa nilai koefisien determinasi berada diantara nol atau satu, masing - masing variabel bebas berupa current ratio, debt to equity ratio,total asset turnover mempunyai kemampuan $20.9 \%$ dalam menjelaskan variabel dependennya berupa net profit margin, sedangkan $79.1 \%$ dijelaskan oleh faktor lainnya yang tidak diteliti dalam penelitian ini.

Uji Simultan atau Uji statistik F pada dasarnya menunjukkan apakah semua variabel independen atau bebas yang dimasukkan dalam model mempunyai pengaruh secara bersama-sama terhadap variabel dependen/terikat, hasil dari uji $\mathrm{F}$ dapat dilihat dalam tabel 1.3 sebagai berikut:

Tabel 1.3 Uji F

\begin{tabular}{|c|c|c|c|c|c|c|}
\hline \multicolumn{7}{|c|}{ ANOVAa $^{a}$} \\
\hline & Model & Sum of Squares & Df & Mean Square & $\mathrm{F}$ & Sig. \\
\hline \multirow{3}{*}{1} & Regression & 7.897 & 3 & 2.632 & 3.727 & $.023^{\mathrm{b}}$ \\
\hline & Residual & 19.776 & 28 & .706 & & \\
\hline & Total & 27.673 & 31 & & & \\
\hline
\end{tabular}

a. Dependent Variable: LN_Net_Profit_Margin

b. Predictors: (Constant), LN_Total_Aset_Turnover, LN_Debt_To_Equity_Ratio, LN_Current_Ratio

Uji signifikansi simultan/ bersama-sama (uji statistik F) menghasilkan nilai F hitung sebesar 3.727 Pada derajat bebas $1\left(\mathrm{df}_{1}\right)=3$, dan derajat bebas $3\left(\mathrm{df}_{2}\right)=28$. Nilai f tabel pada taraf kepercayaan signifikansi 0,05 adalah 2,95 dengan demikian $F_{\text {hitung }}=3.727>\mathrm{F}$ tabel $=2,95$ dengan tingkat signifikansi 0,023lebih besar dari 0,05 maka Hoditerima artinya secara bersama-sama current ratio, debt to equity ratio, total asset turnover berpengaruh terhadap net profit margin pada Perusahaan Otomotif dan komponennya yang terdaftar di Bursa Efek Indonesia pada periode 2013-2016.

Uji parsial atau Uji statistik t pada dasarnya menunjukkan seberapa jauh pengaruh satu variabel penjelas/independen secara individual dalam menerangkan variasi variabel dependen, hasil dari uji $\mathrm{F}$ dapat dilihat dalam tabel 1.4 sebagai berikut:

Tabel 1.4 Uji t

\begin{tabular}{|c|c|c|c|c|c|c|c|c|}
\hline \multicolumn{9}{|c|}{ Coefficients $^{a}$} \\
\hline & \multirow[t]{3}{*}{ Model } & \multirow{2}{*}{\multicolumn{2}{|c|}{$\begin{array}{c}\text { Unstandardized } \\
\text { Coefficients }\end{array}$}} & \multirow{3}{*}{$\begin{array}{c}\text { Standardized } \\
\text { Coefficients } \\
\text { Beta }\end{array}$} & \multirow[t]{3}{*}{$\mathrm{t}$} & \multirow[t]{3}{*}{ Sig. } & \multicolumn{2}{|c|}{ Collinearity Statistics } \\
\hline & & & & & & & & \\
\hline & & B & Std. Error & & & & Tolerance & VIF \\
\hline \multirow{4}{*}{1} & (Constant) & -3.131 & .201 & & -15.613 & .000 & & \\
\hline & LN_Current_Ratio & -.173 & .171 & -.167 & -1.016 & .318 & .944 & 1.060 \\
\hline & LN_Debt_To_Equity_Ratio & -.536 & .241 & -.361 & -2.224 & .034 & .970 & 1.031 \\
\hline & LN_Total_Aset_Turnover & -.731 & .265 & -.453 & -2.759 & .010 & .945 & 1.058 \\
\hline & endent Variable: LN_Net_P & t_Margin & & & & & & \\
\hline
\end{tabular}


Nilai t tabel untuk probabilitas 0,05 pada derajat bebas $N=28$ 1.70113. Dengan demikian hasil uji t dapat dijelaskan sebagai berikut; hasil perhitungan uji t secara parsial diperoleh nilai t hitung current ratio sebesar -1.016 dengan nilai signifikan sebesar 0,318. Nilai -t tabel<-t hitung atau $-1.70113<-1.016$ maka $\mathrm{H}_{0}$ diterima artinya current ratiotidak berpengaruh terhadap net profit margin pada perusahaan Otomotif dan komponennya yang terdaftar di Bursa Efek Indonesia pada periode 2013-2016.

Hasil perhitungan uji t secara parsial diperoleh nilai t hitung debt to equitysebesar 2.224 dengan nilai signifikan sebesar 0,034. Nilai t hitung $>t$ tabel atau $2.224<1.70113$ maka $\mathrm{H}_{a}$ diterima artinya debt to equityberpengaruh negatif terhadap net profit margin pada perusahaan Otomotif dan komponennya yang terdaftar di Bursa Efek Indonesia pada periode 2013-2016. Hasil perhitungan uji t secara parsial diperoleh nilai t hitung total asset turnover sebesar -2.759 dengan nilai signifikan sebesar 0,010. Nilai t hitung $<\mathrm{t}$ tabel atau 2.759> 1.70113 maka $\mathrm{H}_{\mathrm{a}}$ diterima artinya total asset turnover berpengaruh negatif terhadap net rofit margin pada perusahaan Otomotif dan komponennya yang terdaftar di Bursa Efek Indonesia pada periode 2013-2016.

\section{Pengaruh Current RatioTerhadap Net Profit Margin}

Dari hasil pengolahan data diperoleh nilai $t$ hitung Current Ratiosebesar 1.016dengan nilai signifikan sebesar 0,318 . Nilai -t tabel < -t hitung atau $-1.70113<$ 1.016dengan demikian $\mathrm{H}_{0}$ yang menyatakan current ratio tidak berpengaruh terhadap net profit margin pada perusahaan Otomotif dan komponennya yang terdaftar di Bursa Efek Indonesia pada periode 2013-2016. Menurut Horne dan Wachowich (2014:254), profitabilitas berbanding terbalik dengan likuiditas. Peningkatan likuiditaas biasanya dibayar dengan penurunan profitabilitas. Hasil penelitian ini tidak sama dengan hasil penelitian Frecanza (2016) yang menemukan adanya pengaruh current ratioterhadap net profit margin. Berdasarkan hasil penelitian current ratiotidak berhubungan terhadap net profit margin. Hal ini menunjukan bahwasanya hutang lancar tidak meningkatkan laba bersih. Hal ini disebabkan manajemen perusahan yang kurang baik dalam melakukan aktivtas perusahaan.

\section{Pengaruh Debt to Equity RatioTerhadap Net Profit Margin}

Dari hasil pengolahan data diperoleh nilai t hitung debt to equity ratiosebesar 2.224dengan nilai signifikan sebesar 0,034. Nilai t hitung $>t$ tabel atau $2.224<1,70113$ dengan demikian $\mathrm{H}_{\mathrm{a}}$ yang menyatakan debt to equity ratio berpengaruh negatif terhadap net profit marginOtomotif dan komponennya yang terdaftar di Bursa Efek Indonesia pada periode 2013-2016. Menurut Jusuf (2008:56), semakin tinggi debt to equity ratio maka resiko kreditor (termasuk bank) semakin besar karena debt to equity ratio yang tinggi berarti semakin rendah tingkat keamanan dana yang ditempatkan oleh kreditor dalam bisnis tersebut. Hasil penelitian ini sejalan dengan hasil penelitian Koto,Debt to Equity Ratio berpengaruh terhadap Net Profit Margin. Hasil penelitian ini sejalan dengan peneliti sebelumnya, penelitian ini menunjukan debt to equity ratio berhubungan terhadap net profit margin. Hal ini menunjukkan bahwasanya debt to equity bisa menaikan penghasilan perusahaan.

\section{Pengaruh Total Aset TurnoverTerhadap Net Profit Margin}

Dari hasil pengolahan data diperoleh nilai t hitung total asset turnoversebesar 2.759dengan nilai signifikan sebesar 0,010. Nilai t hitung $>t$ tabel atau $2.759<1,70113$ dengan demikian $\mathrm{H}_{\mathrm{a}}$ yang menyatakantotal asset turnoverberpengaruh negatifterhadap net profit margin pada perusahaan Otomotif dan Komponennya yang terdaftar di Bursa 
Efek Indonesia periode 2013-2016. Menurut Mamduh (2008), semakin tinggi angka perputaran aktivanya,. semakin efektif perusahaan mengolah asetnya. Robbert (1997), semakin besar TATO akan semakin baik karena semakin efisien seluruh aktiva yang digunakan untuk menunjang kegiatan penjualan. Hasil penelitian ini yang menunjukkan total asset turnover berpengaruh secara positif dan signifikan terhadap net profit margin saham sejalan dengan penelitian ini. Berdasarkan hasil penelitian tersebut hal ini sejalan dengan peneliti sebelumnya, penelitian ini mengatakan bahwa total asset turnover berhubungan terhadap net profit margin. Hal ini menunjukkan bahwa perputaran aktiva yang meningkat dapat meningkan laba perusahaan karena manajemen yang kurang baik.

\section{SIMPULAN}

Kesimpulan dari hasil penelitian ini adalah ; Untuk Current Ratio hasilnya tidak berpengaruh terhadap Net Profit Margin pada perusahaan Otomotif dan Komponennya yang terdaftar di Bursa Efek Indonesia pada periode 2013-2016. Debt to Equity Ratio berpengaruh terhadap Net Profit Margin pada perusahaan Otomotif dan Komponennya yang terdaftar di Bursa Efek Indonesia pada periode 2013-2016. Total Aset Turnover berpengaruh terhadap Net Profit Margin pada perusahaan Otomotif dan Komponennya yang terdaftar di Bursa Efek Indonesia pada periode 2013-2016. Current ratio, debt to equity ratio, total asset turnover berpengaruh terhadap net profit margin pada perusahaan Otomotif dan Komponennya yang terdaftar di Bursa Efek Indonesia pada periode 2013-2016. Hasil Koefisien Determinasi menunjukkan 20.9\% dari variabel dependen Net Profit Margin yang dapat dijelaskan oleh variabel independen Current Ratio, Debt to Equity Ratio, Total Asset Turnover sedangkan sisanya sebesar 79.1\% dijelaskan oleh variabel-variabel yang ditidak ada dalam penelitian ini.

Saran dari hasil penelitian dapat ditujukan bagi peneliti selanjutnya, disarankan sebagai bahan referensi untuk penelitian selanjutnya dengan variabel yang berbeda karena hasil penelitian ini baik secara simultan maupun parsial Curent Ratio, Debt to Equity, dan Total Asset Turnovertidak berpengaruh terhadap Net Profit Margin. Bagi Perusahaan, agar memperhatikan Current Ratio karena hasil penelitian menunjukkan bahwa kenaikan Current Ratioakan menyebabkan penurunan Net Profit Margin disarankan menurunkan penggunaan Current Ratio terlebih dahulu. Bagi Investor, berdasarkan hasil penelitian ini Debt to Equity Ratio, dan Total Asset Turnoverdapat dijadikan pedoman untuk melihat kenaikan ataupun penurunan net profit margin karena hasil penelitian menunjukkan Debt to Equity Ratio, dan Total Asset Turnover berpengaruh terhadap Net Profit Margin.

\section{DAFTAR PUSTAKA}

Barus, A. C. (2013). Analisis Faktor-Faktor yang Mempengaruhi Profitabilitas pada Perusahaan Manufaktur yang Terdaftar di Bursa Efek Indonesia. Jurnal Wira Ekonomi Mikroskil: JWEM, 3(2), 111-121.

Basuki, A., \& Djoko, S. (2012). Analisis Pengaruh Cash Ratio, Debt To Total Assets Ratio, Debt Equity Ratio, Return On Assets, Dan Net Profit Margin Terhadap Dividend Payout Ratio Pada Perusahaan Otomotif yang Listing di Bursa Efek Indonesia Periode 2007-2011 (Doctoral dissertation, Fakultas Ekonomika dan Bisnis). Universitas Diponegoro Semarang

Dewi, S. P., \& Hidayat, R. (2019). Pengaruh Net Profit Margin dan Return on Assets terhadap Harga Saham pada Perusahaan Otomotif yang terdaftar di Bursa Efek Indonesia. Jurnal Ilman: Jurnal Ilmu Manajemen, 1(1).

Harahap, Sofyan. Syafri. 2013. Analisis Kritis atas Laporan Keuangan. Jakarta: Penerbit PT. Raja Grafindo Persada.

Hery. Analisis Laporan Keuangan Pendekatan Rasio Keuangan. Yogyakarta: CAPS, 2015 
Horne, James C dan John M. Wachowics, Jr. Prinsip-prinsip Manajemen Keuangan. Edisi 13. Buku 1. Jakarta: Salemba Empat, 2012.

Jumingan. Analisis Laporan keuangan. Cetakan kelima. Jakarta: PT. Bumi Aksara, 2014.

Jusuf, Jopie. Analisis Kredit untuk Account Officer. Jakarta: PT. Gramedia Pustaka Utama, 2008.

Kasmir. Analisis Laporan Keuangan. Cetakan kelima. Jakarta: PT. RajaGrafindo Persada, 2012.

Keown, dkk. Manajemen Keuangan. PT. Indeks, 2008.

Samryn, L.M. 2013. Akuntansi Manajemen: Informasi Biaya Untuk Mengendalikan Aktiva Operasi dan Informasi. Jakarta: Penerbit Kencana Prenadamedia Group.

Sartono, R.Agus. Manajemen Keuangan Teori dan Aplikasi: Ed. 4, Yogyakarta: BPFE, 2012.

Sitanggang J.P., Manajemen Keuangan Perusahaan. Cetakan Pertama. Jakarta: Penerbit Mitra Wacana Media, 2012.

Subramanyam \& John J. Wild. 2011. Analisis Laporan Keuangan. Edisi 10,Jakarta: Penerbit Salemba Empat.

Suntoyo, Danang. Dasar-Dasar Manajemen Keuangan Perusahaan. Yogyakarta: Alfabeta, 2011.

Syamsuddin, Lukman. Manajemen Keuangan Perusahaan. Jakarta: Penerbit PT. RajaGrafindo Persada, 2007. 